\title{
BAŞKANLIK KONUŞMASI ÖLDÜREN EĞLENCE: BİR ÖRNEK OLAY INCELEMESI
}

\section{Enes DÖNMEZ ${ }^{1}$}

\begin{abstract}
öz
Bu çalışmanın amacı; ABD Başkanı Donald Trump'ın, 2019 yılında terörist lider Ebubekir El-Bağdadi'nin ABD kuvvetleri tarafından öldürüldüğünü açıkladığı konuşması ile Barrack Obama'nın başka bir terörist lider olan Usame Bin Ladin'in 2011 yılında öldürüldüğünü açıkladığı konuşmalarını karşılaştırarak; göstergebilimsel ve metinlerarası bir analiz ile gösteri olgusu ekseninde değerlendirmektir. ABD medyasında içeriklerin ne türden olursa olsun eğlence formatına evirilebildiği daha önce birçok çalışmada yer almıştır. Medya aktörleri de bu 'cümbüş' içinde kimi zaman dikkat çekmek, kimi zamanda dikkatleri başka yöne çekmek amacıyla gösteri olgusuna başvurmaktadır. Trump öncesi başkanlar Irak ve Afganistan'da yer almalarının sebebi olarak demokrasi, barış ve anti-terörizm gibi olguları dile getirirken, Trump diğer başkanlardan farklı olarak petrol için orada olduklarını, Orta Doğu'dan maddi gelir elde etmeleri gerektiğini, oraya ne ölçüde bir yatırım yaptıklarını açıkça dile getirmektedir. Bu doğrultuda Trump'ın eski bir reality show sunucusu olarak da gösteriyi medyada nasıl kullandığı ve oluşturmak istediği anlamı nasıl inşa ettiği bu çalışmada incelenmiştir.
\end{abstract}

Anahtar Sözcükler: Başkanlık Konuşması, Trump, Gösteri, Obama.

\section{AMUSING OURSELVES TO DEATH IN PRESIDENTIAL ADDRESSES: AN ANALYSIS OF A CASE STUDY}

\begin{abstract}
The purpose of this study is to evaluate the statement of the U.S. President Donald Trump upon the death of the Terrorist Leader Abu Bakr al-Baghdadi in 2019 and the statement of the former president Barack Obama upon the death of the Terrorist Leader Osama bin Laden in 2011, by comparing these two statements on the axis of the phenomenon of spectacle, with a semiotic and intertextual analysis method. So far, many studies have shown that the contents of the U.S. Media, regardless of their types, could turn into the amusement format. In this razzledazzle, media actors apply to the phenomenon of spectacle in order to attract attention and sometimes to draw attention to another direction. While the presidents before Trump used to express the facts such as democracy, peace and anti-terrorism as the reason for their presence in Iraq and Afghanistan; Trump, unlike the other presidents, expresses clearly that they are there for oil, they have to earn material income from the Middle East, to what extent they have invested there. In this regard, how Trump uses the show in the media as a former reality show presenter and how he builds the meaning he wants to create was examined in this study.
\end{abstract}

Keywords: Presidential Addresses, Trump, Spectacle, Obama.

\footnotetext{
${ }^{1}$ Araştırma Görevlisi, İstanbul Arel Üniversitesi, illetişim Fakültesi, enesdonmez@arel.edu.tr, ORCID: 0000-0002-7296-1527
} 
DÖNMEZ, Enes (2020). Başkanlık Konuşması Öldüren Eğlence: Bir Örnek Olay İncelemesi, Gümüşhane Üniversitesi İletişim Fakültesi Elektronik Dergisi (e-gifder), 8 (2), 1081-1110

\section{Giriş}

Alan yazında kaleme alınmış çalışmaların yanında (Suhadi ve Baluqiah, 2017; Belisle vd., 2018; Liu ve Lei, 2018), bazı köşe yazarları Donald Trump'ın Amerika Birleşik Devletleri Başkanı olması ile birlikte yürüttüğü iletişim çalışması hakkındaki düşüncelerini Neil Postman'ın (2016: 7-8) kehaneti 1şı̆̆ında köşelerine taşımışlardır. Postman, George Orwell'ın distopyasındaki kehanetinin değil, Aldous Huxley'in kehanetinin gerçekleştiğini ileri sürmektedir. Orwell, insanların yukarıdan gelen baskılara boyun eğmek zorunda bırakılacağı̆, Huxley ise üzerlerindeki baskıdan hoşlanmaya, düşünme becerilerini tahrip edecek teknolojileri kutsamaya başlayacakları bir toplum tasviri yapmaktadır. Orwell enformasyonsuzluktan korkarken, Huxley pasifliğe ve egoizme sürükleyecek derecede enformasyon bombardımanına maruz kalınacağından korkuyordur. Böylelikle sorun insanlardan hakikatin gizlenmesi değil, insanların hakikati umursamamaları olacaktır. $\mathrm{Bu}$ da Debord'un (2019) dile getirdiği gibi günümüzde gösterinin kabullenilmesine yol açmaktadır. Gösteri medyatiklik veya medya aşırılıkları olarak sunulmaktadır. Medya aşırılıkları kavramı ile medya gibi yüce bir aracın arada bir göz yumulması gereken hatalar yapabileceği, insanlara yine medya aracıllğılyla kabul ettirilmektedir.

Orwell, Huxley, Debord ve Postman; hiçbiri günümüz medyasını ve sosyal medyayı göremediler. Ezrei Klein'in (2018) Vox’ta yayımlanan “Amusing ourselves to Trump" başlıklı yazısı gibi medyada, Postman'ın çerçevesinden Trump değerlendirmeleri yer almaktadır. Bunun yanında, Obama dünyada en çok takipçisi olan Twitter hesaplarından birine sahiptir. Yine Trump'ın Twitter'ı kullanma biçimi sıra dışıdır. Siyaseti ve diplomasiyi alışılmışın dışında Twitter üzerinden de yürütmektedir.

$\mathrm{Bu}$ bağlamda; medyada mizah konusu dahi olmuş olan Obama ve Trump'ın terörist liderinlerin ölümünü açıkladıkları iki konuşma karşılaştırılarak; gösteri ve eğlencenin ABD siyasetindeki geldiği son noktayı araştırmak ve bunun neticelerinin ne olduğu çalışmanın kapsamını ve amacını oluşturmaktadır. Çalışmanın önemi, sadece ABD siyaseti değil, gelecekte dünya siyasal iletişiminin içeriğine de $1 s ̧ 1 k$ tutmasıdır. Orta Doğu'da masum birçok kişinin ölmesine rağmen açıkça bu bölgedeki kendi maddi kaygılarını dile getiren bir başkan, eleştirilmek bir yana bu 
DÖNMEZ, Enes (2020). Başkanlık Konuşması Öldüren Eğlence: Bir Örnek Olay İncelemesi, Gümüşhane Üniversitesi İletişim Fakültesi Elektronik Dergisi (e-gifder), 8 (2), 1081-1110

konuşması ile televizyon programlarının komedi unsuru haline gelmiştir. Bunu da gösteri ve cümbüşün tozpembe tülünün arkasına saklanarak yapmaktadır.

\section{Siyasal illetişimde Başkanlık Konuşmasının Yeri ve Önemi}

Köker'e göre; siyasilerin konuşmaları siyasal iletişimin en eski alanlarından biridir. Seçmenlerin taraflarını ve bu tarafların istemlerini meydana getirmesi bakımından en işlevsel ve anlamlı boyutunu oluşturmaktadır (Köker, 2007: 10). Perloff'a göre ise; siyasal iletişimin en önemli kısmı olarak siyasal konuşma; dil ve göstergeler üzerinden bir anlam düşünmek ve harekete geçirmek olarak görülebilir. Liderler, dilin gücünü kuşanırlar. Renkli ifadeler, uygun metaforlar, söz dizimleri ve ritim gibi unsurları kullanarak tutumları biçimlendirir ve yurttaşları harekete geçirirler (Perloff, 2010: 30).

Siyasiler arasında ise dünyanın en önemli figürlerinden biri ABD başkanıdır. $\mathrm{Bu}$ anlamda $\mathrm{ABD}$ başkanlarının yer aldığı etkinliklerde yaptıkları her türlü konuşma büyük bir önem taşımaktadır. Halkla konuşmak modern başkanlığın merkezi konumundadır. Başkanların önemli olaylar hakkında uygulamaya konulan yasaları savunmak ve krizler hakkında halkı bilgilendirmek amacıyla konuşma yapmaları her zaman beklenmektedir. Başkanlık konuşması hakkındaki araştırmalar geleneksel anlamda sadece hitabete odaklanırken, günümüzde bu alanın dışına çıkmıştır. Coe'ye göre; alandaki araştırmalar sözlü, yazılı veya görsel formatlarla birlikte resmi veya gayri resmi halka dönük bütün başkanlık konuşmalarını kapsamaktadır. Bu alanda çalışma yapan araştırmacılar genellikle başkanların konuşmalarını; "nasıl?” (mesajın içeriği), “neden?” (mesajın üretimi) ve "ne gibi bir etkiyle?” (mesajın sonucu) bağlamında inceler (Coe, 2017: 1-2);

ABD başkanlarının konuşmaları bir uzmanlık alanı olarak 1980'lere kadar pek ilgi görmemiştir. 1980'lerden sonra ise başkanların kamuya açık konuşmaları siyaset bilimcilerin ilgi alanı olmaya başladı. James Ceaser, Glen E. Thurow, Jeffrey Tulis ve Joseph M. Besette'ın “The Rise of the Rhetorical Presidency” adlı çalışması bu alanda daha fazla araştırma yapılmasını sağladı (Aüstermühl, 2014: 10).

Windt (1986: 112) "Presidential Rhetoric: Definition of a Field Study" adl1 çalışmasında başkanlık konuşması çalışmalarından şu şekilde bahsetmektedir; 
DÖNMEZ, Enes (2020). Başkanlık Konușması Öldüren Eğlence: Bir Örnek Olay İncelemesi, Gümüşhane Üniversitesi İletișim Fakültesi Elektronik Dergisi (e-gifder), 8 (2), 1081-1110

Retorik ve başkanlık bilimi alanında yeni bir çalışma disiplinidir. $\mathrm{Bu}$ disiplindeki araştırmacılar, kamu dilinin ve kamusal argümanların başkanlık yetkisini nasıl etkilediğiyle ilgileniyorlar. Bu çalışmaların temel gayeleri, çağdaş Amerikan başkanlığının ve retorik başkanlığın nasıl işlev görmesi ve çalışması gerektiği konusundaki yasaklayıcı çalışmaları tanımlamaya yardımcı olan tanımlayıcı ve eleştirel çalışmalardır.

$\mathrm{Bu}$ alandaki güncel araştırmaların başında etki sorunu gelmektedir. Başkanlık konuşmalarının hangi koşullarda, ne derece etkili olduğunu araştıran son dönemlerde hazırlanmış ampirik çalışmalar mevcuttur. Başkanlık konuşmalarındaki diğer bir konu ise; araştırmacıların başkanların söylemlerini incelemek için metinlerin doğasında gerçekleşen dönüşümleri ele almalarıdır. Bu konunun iki bileşeni vardır; başkanlık konuşması alanındaki çalışmaların büyümesini sağlayan çevrimiçi veri havuzları ve retoristlere göre başkan konuşmalarını oluşturan şeyin değişmesidir. Bir metin bir başkasının söylediği sözcüklerden çok daha fazla bileşenden oluşmaktadır. Üçüncü ve son sorun ise başkan konuşmalarını inceleyen araştırmacılar, büyük başkan konuşmalarına odaklanarak çalışmalarını yapmışlardır. Ancak büyük başkanlık konuşmalarına olan ilgi yön değiştirmektedir. Bunlar; televizyon, gazete vb. araçlar vasıtası ile kamuoyunu bilgilendirici, özenle hazırlanmış metinlerdir. Açılış konuşmaları, ulusa sesleniş gibi konuşmalar buna örnektir. Ancak medya parçalanmış bir hale geldikçe başkanlar gelenekselin dişında yöntemler ile halka ulaşmaya çalışıyor (Coe, 2017: 4-5).

Campbell ve Jamieson'un (2008) 'Presidents Creating the Presidency: Deeds Done in Words" adlı çalışması 13 başlık altında başkanlık konuşmasının türlerini sıralamıştır; açılış konuşması (inaugural addresses), yükselen başkan yardımcılarının konuşmaları (the speeches of ascendant vice presidents), ulusal anma konuşması (national eulogies), affetme konuşması (pardoning rhetoric), ulusa sesleniş (state of the union addresses), veto mesajları (veto messages), ABD Başkanı'nın bir yasa tasarısının imzalanması sonrası verdiği yazılı beyan (signing statements), başkanın savaş konuşması (presidential war rhetoric), başkanın kendisini savunma konuşması (presidential rhetoric of self-defense), suçlama konuşması (the rhetoric of impeachment), veda konuşması (farewell addresses). Türlerin her biri kendisini 
diğerinden ayıran karakteristik özelliklere sahiptir. Aynı türde konuşan farklı başkanlar tek tip olmasa da benzer temalara sahiptirler.

Halk dolaylı olarak ülkeyi yönetecek kişi ve kişileri, kural koyucuları ve onun ekibini seçerler. Yukarıda belirtilen türlerden olan açılış konuşması ise ABD Başkanı'nın ekibi ve yönetimi hakkında yapacaklarının bir örneğidir (Belisle, 2018: 14). Başkanlar bu konuşma sırasında bir önceki hükümetten bahseder ve gelecekte neler yapacaklarını, hangi başkanın yolunda ilerleyeceklerini ifade ederler. Başkan'ın ilk yaptığ 1 konuşma olması hasebiyle metinlerarasılıktan faydalanmak bazı avantajlar sağlayabilir. Örneğin; Obama'nın başarılı bir demokrat başkandan alıntı yapması kendisinin vaat ettiği yönetim biçimi konusunda dinleyiciler açısından daha anlaşılır olabilir. Başkanlık konuşmalarının medyatik boyutu göz önünde bulundurulduğunda başkanlar akılda kalıcılığı ve etkileyiciliği arttırmak için alışılmışın dışına çıkabilir veya konuşmalarını eğlenceli bir formata çevirmek isteyebilirler. Örneğin; şükran günlerinde $\mathrm{ABD}$ başkanları bir affetme konuşması düzenlemektedir. Bu konuşmada normalde Beyaz Saray tarafindan kesilen hindiler komik bir üslup ile affedilir ve kesilmezler. Diğer yandan Trump'ın aşağıda da belirtilen popüler kültüre ait filmlerden yaptığı metinlerarası ilişkiler ABD ve küresel medyada yer bulmaktadır. $\mathrm{Bu}$ durumda başkanlık konuşmalarının da bir medya gösterisine dönmesine yol açabilmektedir.

\section{Gösteri Makinesi Televizyon}

Guy Debord'a göre (2019), modern toplumlarda gösteri her yanı sarmıştır ve yaşanmış olan her şeyi bir temsile bırakarak uzaklaşmaktadır. Gösteri bir sahtelik değil, gerçektir ve gerçeklik gösterinin içinde belirir. 60'l1 y1llarda 'gösteri toplumu' olgusunu ortaya atan Debord'un görüşleri geçerliliğini korumaktadır. Gösteri yaygınlaşıp herkes tarafindan kullanılmaya başlansa da bu sözcük yerine medyatik sözcügü tercih edilmiştir. Gösteri medya aşırılıklarından ibaret görüldüğü için; iyi olarak kabul görmüş medyanın, bazen aşırı uçlara götürüldüğü söylenir. Debord, Amerika'daki gösteriyi ise yaygın gösteri yani ücretlileri, birbirileriyle rekabete götüren ve dünyanın Amerikalaştırılmasını ifade eden gösteri türüne örnek göstermiştir. 
DÖNMEZ, Enes (2020). Başkanlık Konuşması Öldüren Eğlence: Bir Örnek Olay İncelemesi, Gümüşhane Üniversitesi İletişim Fakültesi Elektronik Dergisi (e-gifder), 8 (2), 1081-1110

Gösteri toplumlarının vazgeçilmezi olan medyada, eğlence her zaman önceliklidir. Bu toplumlarda ticari başarı elde etmenin ön koşulu eğlenceli olmasıdır. Bununla birlikte ekonominin eğlenceye dönüştürülmesi televizyondan sinemaya, hatta lunaparklara kadar eğlence şekilleri toplumun ekonomisini domino etmektedir (Kellner, 2010: 23).

Neil Postman televizyon ile birlikte eğlencenin toplumun birçok alanına sızdığını, televizyonun her şeyi bir eğlence formatına çevirdiğini dile getirmiştir. Postman kitabının "Tipografi Amerika'sı" başlığı altında televizyon öncesi Amerika'yı tasvir ederken şaşırtıcı derecede okuma oranlarının yüksekliğinden, insanların okumaya olan heveslerinin ne kadar çok olduğundan bahsetmektedir. Öyle ki Charles Dickens'ın 1842 yılında Amerika’yı ziyaretinde gördüğ̈̈ ilgi bugün bile film yıldızlarını kıskandıracak cinstendir (2016: 44-55).

Peki bu durum, halka hitap eden politikacılara nasıl yansımaktadır. Abraham Lincoln ve Stephen A. Douglas adlı iki politikacının -ki Lincoln daha sonra ABD başkanı olacaktır- 1858 yılı ve sonrasında yaptıkları halk önündeki tartışmalar bu konuda örnek gösterilmektedir. Postman'a göre; toplamda yedi saatlik konuşmalar olduğu düşünülecek olursa; bu sürede bir konuşmayı dinleyecek kalabalık hayranlık uyandırıcıdır. Süreler dışında konuşmalardaki tavır ve biçimde günümüz politik konuşmalarından oldukça farklıdır. Dönemin politikacıları bilgisi olmadığı konularda bunu kabul edecek olgunluğa sahiptir. Kullandıkları dil ise günümüze göre oldukça ağırdır. Kurulan cümleler yazılı dile ait gibidir. (2016: 61-68). Bugün Amerikan televizyonlarında "Presidential Debate" olarak geçen, daha çok bir boks ringini andıran, başkan adaylarının karşılıklı tartışmaları 2 saat bile değildir. Bu tartışma bir eğlence formatına dönüştürülmüştür ve kullanılan dil Lincoln ya da Douglas'ın kullandığı dile nazaran oldukça basittir.

Gösteri ve eğlence Amerikan siyasetinin birçok yerine nüfuz etmiştir. Buna Amerikan Başkanının kendisi de dahildir. Postman (2016) bunu Ronald Reagan'ın daha önce bir aktör olduğunu söyleyerek, Nixon'un makyajcılarının sabotajı yüzünden seçim kaybettiğini iddia ederken; başka bir aday için de kampanyaya on kilo vererek başlaması gerektiğini söylemesi gibi örnekler ile açıklar. Anayasal bir zorunlulukmuş gibi şişman hiç kimse başkanlığa adaylığını koyamamaktadır. 
DÖNMEZ, Enes (2020). Başkanlık Konuşması Öldüren Eğlence: Bir Örnek Olay İncelemesi, Gümüşhane Üniversitesi İletişim Fakültesi Elektronik Dergisi (e-gifder), 8 (2), 1081-1110

\section{Araştırma}

\subsection{Yöntem}

Çalışmada nitel yöntemle tercih edilmiştir. Sosyal bilimlerde yaygın olarak kullanılan nitel yöntem doğal konuşma içerisinde kaba veriyi toplar, tümevarımsal olarak analiz eder ve elde edilen bağlamlar ve sosyal durumları tanımlar (Decoster ve Lichtenstein, 2012: 390-391).

Çalışma; Obama ve Trump'ın iki konuşmasını nitel araştırma yönteminin desenlerinden biri olan örnek olay deseni ile incelemiştir. Her iki başkanın konuşmaları göstergebilimsel analiz ve metinlerarasılık analizi ile incelenmiştir. Medya metinlerinde yer alan belli kodlar vasıtası ile göstergeler analiz edilmektedir. Bunlar; renk kodları, elbise kodları, sözlü olmayan kodlar (jest ve mimikler, tonlamalar), teknik kodlar, estetik kodlar, bilimsel kodlar, sözlü kodlardır. Bunun yanında bir gösterge; gösteren ve gösterilen ile oluşmaktadır. Aynı zamanda Roland Barthes'ın göstergebilime katkısı olan düz anlam ve yan anlam yaklaşımı; bir gösterge ile karşılaşıldığında akla gelen ilk anlamı olan düz anlamı ve içerisinde ideoloji ve gizli anlamı barındıran yan anlamı ifade etmektedir (Devran, 2010: 33$35)$.

Göstergebilimsel analiz her iki başkanın konuşmasındaki direkt mesajların yanı sıra, konuşmalarında yer alan yan anlamlar ve ideolojik anlamları derinlemesine inceleme imkanı sunmaktadır. Bu ideolojik anlamların hangisini ön plana çıkarmak, hangisinin üstünü örtmek istediklerini yine göstergebilimsel analiz ile ortaya çıkarmak mümkün olmaktadır. Jest ve mimiklerin kullanımı aynı zamanda konuşmalarını ne derece ciddi ya da şova dökmek istediklerini ortaya koymada da oldukça kolaylık sağlamaktadır. Kısaca konuşmanın sözsüz iletişimi ve yan anlamlar, gösterinin olup olmadığını, derecesini gösterdiği gibi; en önemlisi de gösterinin amacını gözler önüne sermektedir.

Aktulum'a göre (2011: 9-17), metinlerarasılık; yazınsal bir kavram ile sinırlanmayıp tüm nesnelerden yeni anlamlar üretmeye imkan sağlayan tutarlı, özgün bir yöntem ve çok yönlü bir okuma imkanı sunan bir yaklaşımdır. Tek başına 
DÖNMEZ, Enes (2020). Başkanlık Konuşması Öldüren Eğlence: Bir Örnek Olay İncelemesi, Gümüşhane Üniversitesi İletişim Fakültesi Elektronik Dergisi (e-gifder), 8 (2), 1081-1110

göstergelerarasılık ise; dilsel olmayan göstergelerin dilsel, dilsel olan göstergelerin ise dilsel olmayan göstergeler ile arasındaki metinlerarası ilişkidir.

Başkanlık konuşmalarında ise metinlerarasılık önemli yer tutmaktadır. Özellikle seçildikten sonra yaptıkları açılış konuşmasında, halk arasında balkon konuşması olarak bilinen konuşmada, ilk defa yönetime gelen başkan genelde kendi partilerinin geçmişteki en popüler ve sevilen başkanlarının konuşmaları ile metinlerarası ilişki kurarlar. Bunlar hem onların başarısından faydalanmanın hem de onlar gibi iyi bir başkan olacağını göstermenin önemli yoludur. Buna örnek olarak; Bush balkon konuşmasında Cumhuriyetçilerin en önemli başkanlarından Ronald Reagon ile Clinton ise John F. Kennedy'nin konuşmaları ile metinlerarası bir ilişki kurmuştur (Aüstermühl, 2014: 1-2). Bu direk alıntı veya biçim olarak alınabileceği gibi; sadece geçmişteki bir başkandan değil, edebiyattan sinemaya kadar her türlü metin ile başkanlar metinlerarası ilişki kurabilirler. Trump'ın balkon konuşmasında "Batman: Kara Şövalye Yükseliyor" filmindeki Bane karakterinin yaptığı bir konuşma ile kurduğu metinlerarası ilişki buna örnektir. (Suhadi ve Baluqiah, 2017: 174). Trump bunun gibi başka filmler ile de metinlerarası ilişki kurmaktadır. Ayrıca, taklit ve canlandırmalar ile de metinlerarasılıktan faydalanan Trump, konuşmalarını gösteriye çevirmektedir. Bu anlamda metinlerarası ilişki ve göstergebilimsel analiz Trump ve Obama'nın konuşmalarının aynı içerik ve türde olmasına rağmen; farklılıkları ortaya koymada en fayda sağlayacak iki veri analiz yöntemidir.

\subsection{Araştırma Soruları}

1. Televizyon her tür içeriği araştırma özelinde başkanlık konuşmasını eğlence formatına dönüştürmekte midir?

2. Sürekli eğlence formatı servisi, hem medyada hem de toplumda hakim olan bir gösteri olgusuna sebep olmakta mıdır?

3. $\mathrm{Bu}$ gösteri olgusu servis edilen enformasyonların ardındaki gerçeği görmede bir engel teşkil etmekte midir? 


\subsection{Veri Toplama Araçları}

Araştırmada veri toplama aracı olarak doküman incelemesi yöntemi kullanılmıştır. Bunun için video paylaşım sitesi olan Youtube ve Beyaz Saray’ın resmi web sitesinde görsel ve yazılı dokümanlar incelenmiştir.

Araştırma sorusu bire cevap vermek amacıyla; başkanların hem görsel kodları hem de dili kullanarak televizyonda ciddi bir içerik olan başkanlık konuşmalarını nasıl eğlenceli bir formata çevirdiği, göstergebilim analizi yardımıyla ortaya konulmuştur. İkinci soruya yanıt bulmak amaciyla; televizyonda servis edilen başkanlık konuşmalarının göstergebilimsel analizi ve popüler kültür ile aralarındaki metinlerarasılık gösteri olgusunu açığa çıkarmaktadır. Son olarak; Trump'ın konuşmasının televizyondaki bir eğlence formatına dönüşmesi başkanların politikalarındaki gerçeği görmede nasıl bir engel teşkil ettiği aşağıda sunulmuştur.

\subsection{Veri Analizi ve Bulgular}

\subsubsection{Barack Hussein Obama'nın Konuşmasının Göstergebilimsel Analizi}

\subsubsection{Obama'nın Sözsüz İletişimi}

Konuşmasında, ekranda görüldüğü şekli ile Obama genel olarak mimiklerini minimize etmiştir. Genel ifadesi kararlılıktır. Ailelerinden kopartılan çocuklardan bahsederken kaşlarını çatmaktadır. Ladin'in öldürülmesini duyurmasının ardından, süreci ve durumu açıklamaya başlayana kadar ifadesizliğinin yerini jestleri almaya başlar. Özellikle vurgulamak istediği yerlerde sözcüklerinin altını çiziyormuşçasına eli ile jestler gerçekleştirir. 9/11'inardından (11 Eylül terör saldırısı) Amerikan halkının birleştiğini sözleriyle işaret ederken; işaret parmağıyla da bunu desteklemektedir. Ladin'i yakalamanın en önemli görevleri olduğunu söylediği kısımda elini yumruk şeklinde sıkarak hafifçe sallamaktadır. Savaşlarının İslam ile olmadığını ve Bin Ladin'in Müslüman olmadığını söylerken, eliyle bu sözlerinin altını çiziyormuşçasına jestler sergilemektedir ve başını iki yana sallayarak yine anlatımını desteklemektedir.

Konuşmasına ciddi bir ses tonuyla başlayarak; Ladin'in ölümünü açıkladıktan sonra, daha duygusal bir ses tonu ve tonlama ile 9/11'in zararlarına hem 
DÖNMEZ, Enes (2020). Başkanlık Konuşması Öldüren Eğlence: Bir Örnek Olay İncelemesi, Gümüşhane Üniversitesi İletişim Fakültesi Elektronik Dergisi (e-gifder), 8 (2), 1081-1110

logos(mantıksal) hem de pathos(duygusal) şeklinde yer verir. Bu duygusal konuşma 9/11'de yakınlarını kaybedenlere seslenirken de devam etmiştir.

\subsubsection{Konuşmanın Sentaktik ve Pragmatik İncelemesi}

Obama konuşmasına Ladin'in ABD tarafından düzenlenen bir operasyon ile öldürüldügünü açıklamasıyla başlayıp, 9/11'i ve etkilerini anlatması ile devam etmektedir. Ardından 9/11'in sorumlusu olan El-Kaide ve lideri Usame Bin Ladin'e açılan savaş ve Ladin'in yakalanma sürecinden bahsetmektedir. El-Kaide ile olan savaşın kime karşı olduğunun/olmadığının altını çizer. El-Kaide’nin ulusal ve küresel tehdit olduğu ifadelerine yer verir. ABD'nin savaş istemediğinden, savaşa mecbur edildiğinden ve savaşın sonuçlarının kötü olduğundan bahsetmektedir. 9/11'den büyük ders çıkardıklarını, ulusu, dostları ve müttefiklerini korumak için elinden geleni yapacağını söylemektedir. Operasyonda yer alan asker, istihbarat, terörle mücadele uzmanları ve Pakistan yönetimine teşekkür etmektedir. 9/11'de sevdiklerini kaybedenlere ve tüm dünyaya; adaletin yerini bulduğunun ve bir daha böyle bir olayın olmayacağının taahhüdünü vermektedir. Son olarak bütün bunları zenginlik ve güç için değil, adalet ve diğer yüce şeylere hizmet etmek için yaptığını söyleyerek, iyi temenniler ve dua ile bitirmektedir. Sebep-sonuç ilişkisi ile birbirine bağlanan yapılar ile konuşmasının dizimsel yapısını oluşturmuştur.

Obama, Ladin'in öldürüldüğünü açıkladığı ilk cümlelerinde, “öldürülen masum insanlar", "terörist lider”, "kadın”, “erkek" ve “çocuk” gibi sözcükleri kullanmayı tercih etmiştir. Açıklamayı Amerikan halkının yanı sıra dünyaya da yaptığını belirtir. Saldırının düzenlendiği eylül ayı; "parlak, bulutsuz gökyüzü” gibi ifadeler ile anlatılmıştır. Bunun yanında 11 Eylül saldırısı; "kara duman", "yıkım", “enkaz” gibi sözcükler ile anlatılmıştır. O gün mücadele verenlerden bahsederken; "kahraman”, "kalbi kırık” ve “yıkık” gibi ifadeler kullanılmıştır.

11 Eylül sonrası oluşan birlik ruhundan bahsederken; "din", “dil”, "1rk" gibi sözcüklere yer vermiştir. El-Kaide'ye karşı savaş açtıklarını söylerken; “vatandaş”, “dost" ve "müttefik" vurgusu yapmıştır. Yine bu üç vurgu Taliban hükümetini devirdiklerini, teröristleri öldürdüklerini ve 9/11 sorumlularını yakaladıklarını söylerken de belirtilmiştir. Kendi emri ile düzenlenen operasyondan bahsederken; 
DÖNMEZ, Enes (2020). Başkanlık Konușması Öldüren Eğlence: Bir Örnek Olay İncelemesi, Gümüşhane Üniversitesi İletișim Fakültesi Elektronik Dergisi (e-gifder), 8 (2), 1081-1110

"küçük bir Amerikan birliğii”, “yüksek cesaret", "yaralanmadan”, "siviller zarar görmeden”, “öldürmek” ve "bedenini teslim almak” gibi ifadeler tercih etmiştir.

ABD’nin savaşının İslamiyet ile değil, Ladin ile olduğunu söylerken; Ladin'in Müslüman olmadığını ve birçok müslümanın katili olduğunu ifade etmiştir. Bu kısımda Ladin' in ölümünden bahsederken; "demise" ifadesini kullanmıştır. Amerikan'ın bütün bu karmaşanın içinde olmasından bahsedilirken; “seçim”, “ABD kıyıları", “anlamsız katliamlar” ifadeleri kullanılır. Yine "savaşın bedeli”, “mücadele”, "hizmet”, “fedakârlık” ifadeleri vurgulanmış, başkomutanlık unvanı öne çıkarılmıştır. Savaşın bedeli olarak; "sevenlerini kaybedenler" ve "yaralıların gözleri” ifadelerine yer verilmiştir. Ülke savunması konusunda acımasız olacaklarını ve sıfır tolerasyon göstereceklerini belirtir. Yine benzer üçleme "ulus", "dost” ve “müttefik” ifadelerini kullanır. "Bizi biz yapan değerler” vurgusu yapar.

Operasyonda yer alanlara teşekkür ederken; “isimsiz kahramanlar” olarak nitelendirir. Tatmin edici bir iş becerdikleri ve adalet vurgusu yapmaktadır. Operasyonu düzenleyenleri "adamlar (men)" olarak nitelendirir. Son olarak; bütün bunları yapmalarının sebebinin güç ve zenginlik olmadığını söylerken; “bölünmezlik", "tek millet”, “tanrının altında", “özgürlük” ve "adalet” gibi ifadeler kullanmıştır. "Tanrı" ve "Amerika Birleşik Devletleri” ifadeleri ile konuşmasını sonlandırmıştır.

\subsubsection{Obama'nın Konuşmasındaki Göstergeler}

Gösterge: Barrack Obama'nın 2011 yılında Usame Bin Ladin'in ölümünü açıkladığı konuşmanın videosu.

Belirtisel gösterge: Ladin ve El-Kaide; katliam, 11 Eylül saldırısı ve ABD’nin en önemli düşmanının göstergesidir.

Düz anlam: Birçok terör suçundan sorumlu olan El-Kaide lideri Ladin'in öldürülmesi.

Yan anlam: Ladin birçok insanın gözünde zaten suçlu olan biri olmasına rağmen; Obama ABD’nin birini öldürdüğünü açıklarken, bu ölümü sağlam gerekçelerle ve ideolojiler ile kabul ettirmek istemektedir. 
DÖNMEZ, Enes (2020). Başkanlık Konuşması Öldüren Eğlence: Bir Örnek Olay İncelemesi, Gümüşhane Üniversitesi İletişim Fakültesi Elektronik Dergisi (e-gifder), 8 (2), 1081-1110

Obama konuşmasının devamında 11 Eylül olaylarını anlatırken dinleyicilerin o günleri tekrar gözlerinin önüne getirmesi için o dönemde ekranlarda görülen görsellerden, faydalanmıştır.

Gösterenler: Parlak ve bulutsuz eylül ayındaki gökyüzü, gökyüzünden gelen kaçırılmış uçaklar, İkiz Kulelerin yıkılış anı, Pentagon'daki gökyüzüne yükselen kara dumanlar, 93 sayılı uçağın Pensilvanya'daki enkazı ve enkazdakileri kurtaran insanlar.

Düz Anlam: Amerikan halkının hafızasından silinmesi güç olan görseller.

Gösterilen: Hayatını kaybeden insanlar, önemli bir ticaret binasının yıkılışı, güvensizlik.

Yan Anlam: 11 Eylül sonrası dünya eskisi gibi olmamıştır. Amerikan’ın güvenli bir yer olduğu miti yıkılmış ve ABD halkı medyanın da yoğun etkisi ile paranoyak olma seviyesinde güvensiz bir yaşam sürdüğünü düşünmeye başlamıştır. Obama bu görüntülerin tekrar hafizalarda canlanarak, ne kadar doğru bir iş yaptıklarını ispatlamaya çalışmaktadır.

Gösteren: Akşam yemeklerindeki boş sandalye, ailesinden ayrı büyüyen çocuklar, çocuklarının sarılmasından mahrum edilmiş ebeveynler, 3.000'e yakın $\mathrm{ABD}$ vatandaşının hayatını kaybetmesi.

Düz Anlam: 9/11'de sevdiklerini kaybeden insanların medyada yer almayan ve sürekli hissettikleri acıları ve kayıpları. 3.000 kişinin hayatını kaybetmesi ise; bu acıları çeken on binlerce yakını olduğunu göstermektedir.

Yan Anlam: 9/11'de sevdiklerini kaybeden insanların hayatları devam ediyor ve medyada yer almasa da onlar kayıplarının acılarını her an hissediyorlar. Bunun eksikliği ile yaşıyor ve adalet istiyorlar. $\mathrm{O}$ adalet ise; Usame bin Ladin'in ölmesi ve El-Kaide'nin çökertilmesidir.

Düz Anlam: 9/11 sonrası Amerikan halkı bir araya gelerek, komşulara yardım etti, yaralılara kan verdi, toplum ve ülke sevgisi yenilendi. İnsanların nereli olduğu, hangi dine inandıkları, hangi ırk ya da etnik kökenden oldukları önemsenmedi. Bir Amerikan ailesi olarak birleşildi. 
DÖNMEZ, Enes (2020). Başkanlık Konuşması Öldüren Eğlence: Bir Örnek Olay İncelemesi, Gümüşhane Üniversitesi İletişim Fakültesi Elektronik Dergisi (e-gifder), 8 (2), 1081-1110

Yan Anlam: Ladin, Amerika'ya zarar vermek, bölmek isteyen bir terör örgütü lideriydi ve bu amaçla saldırılar düzenledi. Ancak 9/11 sonrası Amerikan halkı birbirine daha sıkı bağlandı, ayrılıkları unuttu.

Düz Anlam: El-Kaide ve Ladin'e büyük zararlar verildi. Taliban hükümeti Ladin'i desteklediği için indirildi. Yine de Ladin Afganistan'dan Pakistan'a kaçmay1 başardı. ABD bunları tek başına değil; müttefik ve dostları ile birlikte yaptı.

Yan Anlam: ABD El-Kaide ile mücadelenin başını çekmektedir. Dostları ile müttefikleri sadece ona yardım etmektedir. Bütün gücünü kullanmasına rağmen ElKaide'ye çok büyük zararlar verse de Ladin'i yakalamak çok zordu ve onu yakalamak çok önemli idi.

Düz Anlam: Obama'nın göreve gelir gelmez CIA direktörüne en öncelikli güvenlik görevlerinin Ladin'i bulmak, yakalamak ya da öldürmek olduğunu söylemesi ve sonrasında uzun süren bir süreçte Ladin'in yakalanıp öldürülmesi.

Yan Anlam: Ladin'i yakalamak çok zor bir iştir. Onu ancak Obama ve ekibi, ama netice itibari ile Obama, başarmıştır.

Hemen devamında Ladin'in El-Kaide için bir sembol olduğunu, yani sembolik bir göstergeye sahip olduğunu belirtmektedir. Ladin'in öldürülmesi ElKaide için bir mitin yıkılması, büyük bir yenilgi ve ABD için tarihsel bir başarının göstergesidir.

Düz Anlam: Obama Müslümanlar ile savaşmadıklarını, daha öncesinde ve hiçbir zaman İslamiyet ile savaşmayacaklarını belirtmiştir. Ladin'in bir Müslüman olmadığını ve birçok Müslümanı öldürdüğünü ifade etmiştir.

Yan Anlam: ABD’nin mücadelesini haklı çıkartmak, Müslümanların ABD’yi düşman olarak görmesini engellemek.

Buradaki göstergeleri desteklemek için; Pakistan gibi Müslüman bir ülke ile yaptıkları iş birliği ve Ladin'in Pakistan'a yaptığı saldırılar örnek olarak gösterilmiştir.

Düz Anlam: Başkomutan olarak yakınını kaybeden aileye mektup imzalamak ve yaralıların gözlerinin içine bakmak. 
DÖNMEZ, Enes (2020). Başkanlık Konuşması Öldüren Eğlence: Bir Örnek Olay İncelemesi, Gümüşhane Üniversitesi İletişim Fakültesi Elektronik Dergisi (e-gifder), 8 (2), 1081-1110

Yan Anlam: Savaşın finansal maliyetini göz ardı ederek, asıl maliyetin hayatını kaybedenler ve yaralılar ile ilgilenmek olduğunu vurgulamıştır.

Düz Anlam: Tanrı sizi korusun ve Tanrı ABD’yi korusun.

Yan Anlam: Dini duyguları ön plana çıkartarak ve halkının dini duygularına hitap ederek konuşmasını sonlandırması; yaptıkları şeylerin yüceliğini anlatmaya çalışmaktır.

\subsubsection{Obama'nın Konuşmasının Metinlerarası Analizi}

9/11 saldırılarının ikonik görselleri olan kaçırılan uçakların ikiz kuleleri yıkması, Pentegon'a düşen uçak, Pensilvanya'ya düşen uçak görsellerini tekrardan dinleyicilerin gözünde canlandırarak metinlerarasılıktan faydalanmıştır. Obama görünmeyen acılardan bahsederken; “akşam yemeklerinde boş sandalye” metaforu yapmıştır. $\mathrm{Bu}$; aileden biri vefat ettikten sonra yapılan bir metafordur. 9/11 sonras1 ise; denverpost.com'da 2008 yılında yazılmış bir mektupta, tıpkı Obama'nın yaptığ şekilde görünen ve görünmeyen acılar şeklinde bir kıyas yapılmış ve akşam yemeğinde boş sandalye metaforu yapılmıştır. Yine bu pasajda çocuklara yaptığ 1 gönderme 9/11 çocuklarını kast etmektedir (http://www.denverpost.com).

Obama'nın konuşmasının bir bölümünde; “O gün, nereden geldiğimiz, hangi Tanrı'ya dua ettiğimiz ya da hangi ırk ya da etnik kökenden olduğumuz önemli değil, bir Amerikan ailesi olarak birleştik”" şeklindeki ifadesi hümanist bir yaklaşım olup, birçok lider ve politikacı tarafindan dile getirilmiş olması muhtemeldir. Bunlara örnek olarak; 1995 yılında Papa 2. John Paul, Birleşmiş Milletlerde yaptığı bir konuşmada "erkek, kadın, tüm dil, din, ırk, dil ve kültürden insanlar" ifadesini kullanarak hitap etmiştir (Paul, 1995). Aynı yıl Clinton yaptığı bir konuşmada; yine 1rk ve farklılık ayrımı yapmadan, "Amerikan çocuğu" ifadesini kullanarak konuşmasını yapmıştır (CNN, 1995). Aynı şekilde “One America in the 21st Century Forging a New Future" adlı çalışma Clinton dönemindeki Başkanın ırk ile ilgili inisiyatifini anlatan bir kitapçıktır. Kitapçıkta Linda Chavez-Thompson adlı bir sendika lideri ve danışman kurul üyesi "Insanlar arasında bir fark olmadiğl, ten renginin, isimlerin bir önemi olmadığını” dile getirmiştir (Beyaz Saray, 1997: 27). ABD birçok ülkeye göre farkl1lıkların çok olduğu bir ülke olduğu için; bu söylemler 
DÖNMEZ, Enes (2020). Başkanlık Konuşması Öldüren Eğlence: Bir Örnek Olay İncelemesi, Gümüşhane Üniversitesi İletişim Fakültesi Elektronik Dergisi (e-gifder), 8 (2), 1081-1110

o yıllardan beri net bir şekilde siyasetin içinde yer almaktadır. Obama da konuşmasında bu söyleme yer vererek, ABD halkının çeşitliliğine dokunmuştur.

Obama savaşlarının Müslümanlar ile olmadığını belirttiği kısımda; Bush’un 9/11'den kısa bir süre sonra yaptığı bir açıklamaya değinerek metinlerarası bir ilişki kurmaktadır. Obama; "amansız (relentless) savunma", "terör ile amansız mücadele" ifadeleri ile metinlerarası bir ilişki kurmuştur. Bush 2001 yılında yaptığı ulusa sesleniş konuşmasında amansız operasyonlar ile teröristleri adalete teslim edeceğini söylemiştir (http://www.washingtonpost.com). 2002 yılında Berlin'de yaptığı bir konuşmasında da bu ifadeye yer vermektedir (http://www.theguardian.com). Obama 2008 yılında kendisi de bu ifadeyi kullanmıştır (http://www.nytimes.com). Ayrıca CIA (2003) "National Strategy For Combating Terrorism" adlı terörle mücadelede ulusal stratejilerini anlattıkları bir kitapçıkta "amansız" ifadesi birkaç defa geçmektedir. Obama konuşmasındaki en belirgin ve etkileyici metinlerarası bağlantıy1; ABD'de “The Pledge of Allegiace” yani bağl1lık sözleşmesi ile kurmuştur (Morris, 2004).

\subsubsection{Donald John Trump'ın Konuşmasının Göstergebilimsel Analizi}

\subsubsection{Trump'ın Sözsüz İletişimi}

Trump'ın arkasında sıralanmış flamalar bulunmaktadır. Bunlar soldan sağa doğru; Amerika Birleşik Devletleri’nin bayrağı, ABD Başkanlığının flaması, "US Army” (ABD Kara Kuvvetleri), "Us Marine” (ABD Deniz Piyade Kuvvetleri), “Us Navy" (ABD Deniz Kuvvetleri), "US Air Force” (ABD Hava Kuvvetleri), "US CoastGuard" (ABD Sahil Güvenlik Teşkilatı) flamaları şeklindedir.

Trump'ın konuşması temelde ikiye bölünmüştür. Bir; Duyuru Kısmı, iki; Soru Cevap Kısmı. Bu iki kısım arasında yapısal olarak farklılıklar belirgin şekilde görünmektedir. Analiz sonucunda da bu ortaya çıkmıştır.

Trump odaya girdiğinde direkt konuşmaya başlamamıştır. Etrafindaki basın mensuplarının hazırlanmasını çok ciddi ve sinirli bir ifade ile bir süre izlemektir. Bazı kişilere başıyla selam verir. Gözlerini bütün odada gezdirmesinin ardından, mikrofonunu düzelttir ve en başta takındığı bütün sert yüz ifadesi bir anda değişir. Duyuru boyunca gergin ama stabil bir yüz ifadesi ile konuşmasını yapmaktadır. 
DÖNMEZ, Enes (2020). Başkanlık Konuşması Öldüren Eğlence: Bir Örnek Olay İncelemesi, Gümüşhane Üniversitesi İletişim Fakültesi Elektronik Dergisi (e-gifder), 8 (2), 1081-1110

Diğer ülkelerden yardım aldığını söylediği kısımda ilk el jestini yapmaktadır. Duyuru kısmı bitince bir rahatlama ifadesi ile soruları ister ve buradan sonra farklılaşan ifadeler sergilemeye başlar. Soru-cevap kısmında, cevaplarında kısa sürelide olsa düşünme esleri vardır. Soru-cevap kısmı ilerledikçe; daha sıradan ve gündelik Trump jest ve mimikleriyle devam etmekte, jest ve mimiklerde artış göstermekte ve duygularını belli etmeye başlamaktadır. 18. dakikadan sonra artık mimik ve jestlerinde artış görülmekte, bu mimikler taklit yaptığı anlarda artmaktadır. Yine aynı şekilde; petrolden, büyük harcamalardan bahsederken ve rakamları telaffuz ederken bu konuları hem tonlamasıyla hem de jest ve mimikleriyle desteklemektedir. Irak'a girildiğinde bunu onaylamadığını, o zamanlar bunu söylediğini ve umursanmadığını söylediği sıralarda ve buna benzer kısımlarda; böbürlenme jest ve mimiklerinde görülmektedir. Açık bir şekilde tonlaması ve hareketleri devleşmektedir. Konuşma boyunca jest ve mimiklerini en ilginç kullandığı kısım; 28:20'de "Knock Kncok May I come in?” diyerek taklit yaptığı kısımdır. Öldürülme gerekçesini 37. dakikada anlatırken yine büyük hareketlerin yanı sıra, eliyle sanki bir bıçakla baş kesiyormuş gibi yapmaktadır. Suriye'den çekilme konusundan bahsederken; net bir şekilde öfkelidir ve büyük jest ve mimikler yapmaktadır. Doğru tahminlerde bulunduğu bir kitap yazdığını söylediği kısımlarda da tonlamasından, jest ve mimiklerinden bir gururlanma olduğu gözlemlenmektedir.

Trump'ın konuşmasının en dikkat çekici tonlaması; Bağdadi'nin adını söylerken yavaş ve heceler şekilde söylemesi olmuştur. Değil başkanlık konuşması, normal bir konuşmada dahi dikkat çekici bir tarzdır. Sözcükler duyuru kısmında uzatılarak okunmaktadır. "Sızlanarak", “ağlayarak", "çığlık atarak”, "köpek gibi”, “korkak bir şekilde” öldüğünü söylerken de bu zarflar konuşma boyunca tonlama ile vurgulanmaktadır. Ölümüyle ilgili farklı zarflar kullanırken; yine üstüne basarak vurgulamıştır. DAEŞ tarafından öldürülenlerin isimlerini vurgularken; bir miktar hüzünlü bir tonlama görülmektedir. 6:33'de "and now he's gone" dediği kısımda, tonlamasında Hollywood aktörleri tarzı bir eda, yüzünde belli belirsiz bir gülümseme ve gurur görülmektedir. Duyurudan, soru-cevaba geçerken; Jest ve mimiklerindeki farklılaşma, tonlamasında da kendisini göstermektedir. "Soru var mı?" diye sorduğu anda son 8 dakikadır yaptığı duyurudan sıkılmış ve kurtulmuş bir ifade ve tonlama 
DÖNMEZ, Enes (2020). Başkanlık Konuşması Öldüren Eğlence: Bir Örnek Olay İncelemesi, Gümüşhane Üniversitesi İletişim Fakültesi Elektronik Dergisi (e-gifder), 8 (2), 1081-1110

gözlemlenmektedir. Soru-cevap kısmında duyurudan farklı olarak normal bir konuşma tonuna geçmektedir. Operasyonda yer alan görevlileri güzellerken; sıfatları vurgulayarak tonlamaktadır. Operasyonda yer alan bakan ve yetkili liderlerin isimlerini sayarken; belirgin bir şekilde sakin ve sıkkın bir tonlama ile konuşmaktadır. Bu isimleri tekrar sayarken, yine aynı tonlama dikkat çekicidir. 20:20 de attığı tweet ile alakalı soru geldiğinde, gülümseyerek ve gayet rahat bir tavırla buna cevap vermiştir. Ancak Suriye'den çekilme ve ABD’nin Orta Doğu politikası ile ilgili konularda jest ve mimiklerinde görülen büyüme, tonlamasında da görülmektedir. İniş çıkışlar artmakta, taklit yaptığı için buda kendi tarzının dışında bir üsluba büründüğü anların görülmesine neden olmaktadır. Petrol hakkında tavsiyeler verirken; didaktik bir ton takınmaktadır. $\mathrm{Bu}$ didaktik tonun yanında; böbürlenen bir tavır ile bir kitap yazdığından ve bu kitapta yazdıklarının doğru çıkmasından bahsetmektedir. Soruların bitmesini beklememekte ya da alakasız cevaplar verdiği anlar konuşmasının genelinde yer almaktadır.

\subsubsection{Konuşmanın Sentaktik ve Pragmatik İncelemesi}

ABD’nin dünyanın bir numaralı terörist lideri El-Bağdadi'yi öldürdüğünü ve onun nasıl biri olduğunu hızlıca bildirir. Başkanlığının en önemli ulusal güvenlik meselesinin Bağdadi olduğunu, ABD timinin gece baskınıyla inanılmaz bir operasyon yaptığını ve birçoğunu izlediğini belirtmiştir. Hiçbir ABD personeli kaybı olmadığını ve Bağdadi’nin savaşçılarının öldüğünü söylemiştir. Bağdadi’nin nasıl öldüğü, yanında götürdüğü 3 çocuktan, bunun yanında 11 çocuğun kurtulduğunu ve Bağdadi'nin kesin ölümünü ifade eder. Tekrar nasıl öldüğünden ve yerleşkede neler ele geçirdiklerinden bahsetmektedir. Bağdadi'nin ölümünün ne ifade ettiğinin, onun ve $H$. Bin Ladin gibilerin rahat uyumaması gerektiğinin altını çizer. DAEŞ ve Bağdadi operasyonlarından dağınık bir şekilde bahsedip, DAEŞ’in infazlarından medyatik olanlar hakkında örnekler verir. Birkaç videodan ve yine nasıl öldüğünden bahseder. Operasyonda yardımı olan milletlere, yer alan ekiplere ve liderlere teşekkür eder. Bağdadi'nin öldüğünü ve bir daha kimseye zarar veremeyeceğini, dünyanın daha güvenli bir yer olduğunu söyler. "Tanrı Amerika’yı korusun” sözleriyle konuşmasını bitirir. İkinci kısım soru-cevap olduğu için gelen sorulara verdiği cevaplar üzerinden bir dizim oluşmaktadır. 
Trump, Bağdadi hakkında "acımasız katil”" ve "şiddetli” ifadelerinin yanında, "korkakça", “ağlayarak”, “çığlık atarak”, “sılanarak” öldüğünü ifade etmiştir. Cesedinin ise parçalandığını, parçalara ayrıldığını ifade etmiştir. Operasyon hakkında ise; "tehlikeli”, “cesurca”, "gösterişli” şeklinde ifadeler kullanmıştır. Bağdadi’nin ölümünün ne ifade ettiğini söylerken; “demise" sözcüğünü kullanmayı tercih etmiştir. DAEŞ’i yenilgiye uğratan kişi olarak kendisini, -yani "Commander-in-Chief of the United States-DAEŞ' in katlettiği kişilerden bahsederken James Foley, Steven Sotloff, Peter Kassig, Kayla Mueller ve Ürdünlü pilotu özellikle vurgular. Turuncu tulum ve kafa kesme gibi DAEŞ suçlarını belirtir. Rusya, Türkiye, Suriye, Irak'a ve Kürtler'e yardımları için teşekkür eder. Operasyona katılanalar için; "en iyi”" ifadesini sık sık vurgulanmıştır. "Hamza Bin Ladin” ve "Usame Bin Ladin”, için “terörist lider” gibi ifadelerin dışında; "uzun”, “yakışıklı” ve "çok karizmatik” gibi sıfatlar kullanmıştır.

\subsubsection{Trump'ın Konuşmasındaki Göstergeler}

Gösterge: Trump'ın Bağdadi’nin ölümünü açıkladığg Youtube videosu.

Düzanlam: Birçok suçtan sorumlu, birçok masum insanı öldürmüş, dünyanın bir numaralı terör liderinin öldürülmesi.

Yan anlam: ABD silahlı kuvvetlerinin ve istihbaratının şaşmaz başarısı, hak etmiş birini öldürmesi ve bu ölümün adaleti simgelemesi.

Düz anlam: ABD hiç kayıp vermedi, DAEŞ Bağdadi başta olmak üzere kayıplar verdi. Bağdadi ağlayarak, sızlayarak ve çığlık atarak öldü.

Yan Anlam: Bağdadi'ye inanmış, onun için savaşan veya savaşmayı düşünen, onun haklı ve cesur olduğunu düşünen insanlara nasıl dehşet içinde ve korkarak öldüğünü; aslında şehit olmak, cennete gitmek gibi anlattığı şeylerin yalan olduğunu, eğer doğru olsaydı cesur bir şekilde ölümü göğüsleyeceğini anlatmak istemektedir.

Düz Anlam: Bağdadi'nin yanında 3 çocuk ölürken, 11 çocuk yara almadan kurtuldu. 
DÖNMEZ, Enes (2020). Başkanlık Konuşması Öldüren Eğlence: Bir Örnek Olay İncelemesi, Gümüşhane Üniversitesi İletişim Fakültesi Elektronik Dergisi (e-gifder), 8 (2), 1081-1110

Yan Anlam: Yetişkinlerde öldürülen sayısının çok olması; bilinçli bir şekilde DAEŞ’e katılanların ölümü hak ettiğini anlatmaya çalışmaktadır. ABD’nin 11 çocuğun hayatını kurtarması çocuklara verdiği değeri, tehlikeli bir operasyonda 11 çocuğun hayatını düşünmesi iyi tarafın kendisi olduğunu göstermektedir. Tam tersi Bağdadi'nin de 3 çocuğu yanında ölüme götürmesi; aslında dünyanın Bağdadi gibilerin elinde olduğunda nasıl kötü bir yer olabileceğini ama ABD olduğu için güvenli bir yer olduğunu göstermektedir. Gelecek emin ellerdedir. Yetişkinler arasında ise ölü sayısının daha fazla olması bilinçli bir şekilde bu örgüte girenlere karşı acımasız olduklarını göstermektedir. $\mathrm{Bu}$ acımasızlık halk nezdinde iyi okunacaktır.

Düz Anlam: ABD güçlerinin zararsız operasyon gerçekleştirmesi.

Yan Anlam: DAEŞ ve Bağdadi'nin daha çok kendisine yakın bölgede bir tehlike olması ve ABD için diğer ülkelere nazaran daha az tehdit olmasından dolayı; ABD askerlerinin böyle bir operasyonda hayatlarını kaybetmesi olumsuz bir gösterge olacaktır. Hiç kayıp olmaması, askerlerin güvenli bir şekilde geri dönmesi önemli bir güç göstergesiyken; diğer yandan ABD halkı için huzur ve güven verici bir unsurdur.

Düz Anlam: ABD kuvvetlerinin Usame ve Hamza Bin Ladin ile Bağdadi’yi öldürmesi

Yan Anlam: ABD’nin mesafe tanımaz gücü her şeye kadirdir.

Düz Anlam: Trump'ın başkan olduğu ilk günden itibaren Bağdadi’yi yakalamak ve öldürmek istemesi, amansız mücadelesi sonucu Bağdadi’nin öldürülmesi ve DNA testi ile öldüğüne dair kesin sonucun elde edilmesi.

Yan Anlam: Bağdadi'nin ABD sayesinde bir daha hiçbir masuma zarar veremeyecek olması, ABD’nin dünyada adaleti sağlayan, kötüler ile savaşan bir kahraman devlet imajı inşa etmesi.

Gösterilen: Turuncu tulumlar ile kafa kesme görüntüleri; James Foley, Steven Sotloff, Peter Kassig gibi isimler ile örneklendirilmiştir.

Düz Anlam: Bağdadi ve DAEŞ; zorla din değiştirmiş, tutsaklarına, Müslüman olmayan kişilere işkenceler yapmış, vahşice öldürmüştür. 
DÖNMEZ, Enes (2020). Başkanlık Konuşması Öldüren Eğlence: Bir Örnek Olay İncelemesi, Gümüşhane Üniversitesi İletişim Fakültesi Elektronik Dergisi (e-gifder), 8 (2), 1081-1110

Yan Anlam: Bağdadi ve DAEŞ'in kurmak istediği sistem bir korku imparatorluğudur. İnfaz görüntülerini tüm dünyaya servis ederek yarattığı bu korkuyu bölgesindeki insanlar üzerinde uygulayarak meydanlarda gerçekleştirmektedir. Bu gibi bir yapının haklı olması mümkün değildir.

Düz Anlam: Trump’ın Rusya, Türkiye, Suriye ve Irak'a teşekkürünün ardından Kürtlere de teşekkür etmesi.

Yan Anlam: Bölgedeki diğer devletler ile bir arada olmanın verdiği imajın yanında; Suriye Kürtlerini ayrıca teşekkürüne ilave etmesi; Trump için de bölgedeki Kürtleri onlar ile bir tutmadığını göstermektedir.

Düz Anlam: Trump'ın diğer ülkelere, Nancy Pelosi ve demokrat senatörlere operasyon hakkında bilgi vermemesi, operasyonu yakın çevresindekiler ve görevliler ile birlikte takip etmesi.

Yan Anlam: Trump demokratların vatana ihanet edecek kadar ileri gidebileceklerini ABD halkına anlatmaya çalışır. Ulusal güvenlik ile ilgili en önemli bir konuda dahi muhalefeti kötülemek amaçlı bir söylem gözetmektedir.

Düz Anlam: Orta Doğu'daki petrolün güven altında tutulması ve Exxon Mobile gibi bir şirkete işletmesinin verilmesini açıkça dile getirmiştir.

Yan Anlam: ABD tarihten bu yana birçok ülkenin iç politikasına karışmıştır. Bunların hepsini demokrasi, barış ve adalet gibi yüce değerler için yaptığını dile getirmiştir. Ancak Trump; neredeyse bunları bir kenara atıp, tek önemli şeyin petrol olduğunu dile getirmektedir. ABD içerde şu anda demokrasi ve adaletten daha çok paraya ihtiyaç duyduğu için; Trump bu söylemlerin ters tepmeyeceği kanaatinde olsa gerek. Ayrıca bu söylemi ABD’nin daha önceki söylemlerini tamamen doğrular biçimde, o dönem petrol için yapıldığını iddia edenlere cevap niteliğindedir.

Düz Anlam: Ladin'in 11 Eylül saldırısından başka ses getirecek eylem yapmamas1.

Yan Anlam: Ladin ve Bağdadi kıyaslaması; net bir şekilde Obama ve Trump kıyaslaması için kullanılmıştır. Trump bu kıyaslama ile 'Obama'nın Ladin'i öldürmüş olması benim yaptığımın yanında çok önemli değil' demektedir. İki terörist 
DÖNMEZ, Enes (2020). Başkanlık Konuşması Öldüren Eğlence: Bir Örnek Olay İncelemesi, Gümüşhane Üniversitesi İletişim Fakültesi Elektronik Dergisi (e-gifder), 8 (2), 1081-1110

liderin katliamları üzerinden kendi başarısını göstermeye çalışmaktadır. Neredeyse Bağdadi daha kötü şeyler yapsaydı diyecek cinsten(!)

Düz Anlam: Trump, Ladin konusunda 11 Eylül öncesi devleti uyardığını söylemekte, bunu da bir kitapta yazdığını belirtmektedir.

Yan Anlam: Beni ABD başkanı yapmak için halk geç kaldı ve zamanında beni dinlemedi. Şimdide kaybetmese iyi eder.

\subsubsection{Trump'ın Konuşmasının Metinlerarası Analizi}

Trump "adalete teslim" etme eski ABD başkanlarından Bush'un da telaffuz ettiği bir ifadedir. Obamada Ladin'in ölümünü duyurduğu sirada bu ifadeyi kullanmıştır. Bağdadi’yi yakalamanın 'en önemli öncelik' olması gibi bir ifade ve ofise gelir gelmez bu konuyla ilgilenmesi yine Obama'nın Ladin konuşmasındaki benzer ifadeleri ile bir metinlerarasılık oluşturmaktadır. Western filmlerinden aşina olunan ‘ölü ya da diri’ yakalama çağrısı da yine Trump'ın yakalamak ve öldürmek söyleminde dikkat çekmektedir.

Terör ile amansız mücadele diğer ABD başkanlarının konuşmalarında olduğu gibi; Trump'ın konuşmasında da yer almaktadır. Trump, Bağdadi ve çevresindeki kaybedenler için "korkak köpek yavruları" şeklinde bir ifade kullanmıştır. Daha öncede konuşmalarında "korkak köpek yavrusu”, "hasta köpek yavrusu” gibi ifadeler yer almaktadır (Kamisar, 2016; Lima, 2017).

DAEŞ'in öldürdüğü masum insanlardan ve Ürdünlü pilotun ölümünün ardından, Ürdün kralının DAEŞ'e savaş açmasından bahsetmiştir. Ardından DAEŞ'in infaz videolarındaki görüntüleri, metinlerarasılıktan faydalanarak anlatmıştır.

Başkan olduğu ilk günden beri "El Bağdadi Nerede? Dedim” şeklinde kendisinden direk alıntı yapmaktadır. Operasyon hakkında Rusya ile ilgili ilişkilerini anlatırken direk alıntı yapmaktadır; “Onlara 'geliyoruz' dedik.”, “Onlar 'söylediğiniz için teşekkürler' dedi.", “Çok mutlu olacağınızı düşünüyoruz' dedik” şeklinde olayları canlandırarak ifade etmektedir. Türkiye'nin oluşturmak istediği güvenli bölge ile ilgili ABD’nin yardımını anlatırken; Kürtlere "Hey sakıncası yoksa 7 mil gidebilir misiniz?” dedik şeklinde alaycı bir ifade kullanır. Avrupa ülkesi vatandaşı 
DÖNMEZ, Enes (2020). Başkanlık Konuşması Öldüren Eğlence: Bir Örnek Olay İncelemesi, Gümüşhane Üniversitesi İletişim Fakültesi Elektronik Dergisi (e-gifder), 8 (2), 1081-1110

olup, DAEŞ'e katılan teröristler yakalanıp ABD'de hapis yatmaktadırlar. Trump ise ülkesinin vergisi ile hapishanede yatan bu kişileri istememektedir ve Avrupa'ya geri vermeye çalışmaktadır. Bu konuya konuşmasında şu şekilde yer vermektedir; “Kişisel olarak Avrupa'ya ama aslında vatandaşlarım adına "DAEŞ teröristlerinizi alın” dedim. Onlarda "Onları istemiyoruz” dediler. Bende "Ĕ̆er onları almazsanız; onları sınırınıza koyacağım ve onları tekrar yakalarken ĕ̆lenebilirsiniz." Bunları söylerken alaycı bir taklit yapmaktadır.

Bush döneminde ABD, Irak'a girerken zamanında bunun karşısında olduğunu ve "Ĕ̆ger oraya gideceksek; petrolü koru” dediğini kendinden alıntı yaparak belirtir. Operasyon sırasında askerlerin Bağdadi'nin saklandığ 1 yere nasıl girmeleri gerektiğini anlatırken; “Tık tık, içeri girebilir miyim?" ş̧eklinde komik bir alıntı yapmıştır. Alaycı bir taklit yapmaktadır.

Bağdadi'den alınan bir örnek ile yapılan DNA testi sonucu ölümünü kesinleşmiştir. $\mathrm{Bu}$ konuyla ilgili sorulan soruya cevap verirken; test sonucunu bildiren yetkiliden direk alıntı yapmıştır. "Bu bir onaylamadır, efendim" First Lady'nin Özel Kuvvetleri eğitimini gördüğünde; “Vaay, daha önce hiç böyle bir şey görmemiştim" şeklindeki etkilenmesini anlatırken direk olarak alıntı yapmıştır.

Bağdadi'nin ölüm şekliyle ilgili sorulan bir soruya; "bazı insanlar 'oh bu biraz şiddetli değil mi?'-Băgdadi'nin korkarak, çı̆̆lık atarak, ăglayarak ve sızlanarak ölme şeklini kast ediyor- diyeceklerdir" şeklinde bir alıntı yapar. Bağdadi'nin ölümünü desteklemek için DAEŞ'in yayınladığı infaz videolarından alınt 1 yaparak bu durumu anlatır. Hatta kafa kesmeyi jestleri ile destekler.

Eski Başkan Bush’un Irak’a gitmesi hakkında o dönem bunun “Muazzam bir hata" olduğunu söylediğini alıntılamıştır. Amerikan petrol şirketlerinin Irak’taki petrol konusunda ayrıma maruz kaldığını, diğer ülkelerin avantajlarından faydalanamadığını duyduğunu söyler. Ancak kaynak belirtmez. "Onlara ne istiyorlarsa verin ama petrolü koruyun” dedim şeklindeki alıntısı; ABD'nin Irak’ta büyük harcamalar ve asker kayıplarının karşıllı̆ında hiç petrolden faydalanamamasının haksızlık olduğunu dile getirir. 
DÖNMEZ, Enes (2020). Başkanlık Konuşması Öldüren Eğlence: Bir Örnek Olay İncelemesi, Gümüşhane Üniversitesi İletişim Fakültesi Elektronik Dergisi (e-gifder), 8 (2), 1081-1110

Görevde bulunduğu üç yıl boyunca sürekli olarak Bağdadi’yi nasıl istediğini anlatırken; ekibindekiler ile arasındaki diyalogları alıntılayarak anlatmaktadır. "Bana, efendim birini yakaladlk diyorlar. Ben de; ben birini istemiyorum. Ben Bă̆dadi’yi istiyorum. İstediğim bu." “Güzel, başka birisini daha yakaladık. Bende harika, güzel, onu yakalayın ama ben Bağdadi'yi istiyorum. Benim istediğim o. Başka insanlar istemiyorum.” Şeklindeki ifadeleri ile alıntı yapmaktadır.

11 Eylül saldırısından önce yazdığı bir kitapta Usama Bin Ladin konusunda uyarılarda bulunduğunu belirtir; "Usame Bin Ladin adında bir adam var. Onu yakalayıp ya da öldürürseniz iyi edersiniz.", "O büyük bir problem." 12 kitap yazdığından ve bir tanesinde Ladin konusunda önceden uyarıda bulunduğundan; farklı alıntılar yaparak bahseder. Şimdiyse bu kitaptan dolayı insanların ona gelip; "Senin hakkında gördüğüm en ilginç şeyin ne olduğunu biliyor musun? Usame Bin Ladin'in Dünya Ticaret Merkezini ylkmadan önce öldürülmesini tahmin etmen” dediğini belirtir. Ama bunu kimlerin söylediği belli değildir. Bu kitapta ise Ladin'in ABD’yi yıkmak istediğiyle ilgili açıklamalarına gönderme yapmıştır.

Operasyon sırasında Trump kendisine dakika dakika nasıl rapor geçildiğini yine operasyonlar sırasındaki konuşmalar ile anlatmaktadır. Yetkililerin "Efendim, şuan içeri girdik”, "Efendim, duvar yıkıldı.", "Efendim, iki kişi dışarı doğru çıkıyor. Elleri yukarıda." ve "Efendim, binada sadece bir kişi kaldı. Tünelden kaçmaya çalıştı̆̆ına eminiz." Sözlerini aktarmaktadır. Son olarak; Bağdadi’nin Kayla’yı görünce onun güzel olduğunu düşünüp, kendine esir olarak aldığını ve sonrada öldürdüğ̈̈nü ima etmektedir.

\section{SONUÇ}

Barack Obama ve Donald Trump'ın konuşmaları karşılaştırıldığında; ilk dikkat çeken kısım konuşma süreleri olmuştur. Obama 9 dakika 18 saniye konuşurken, Trump 48 dakika 5 saniye konuşmuştur. Bunun yanında; Obama operasyon ile ilgili fazla detay vermeden durumu genel çerçevede özetleyip konuşmasını bitirmiştir. Trump ise; detaylardan bahsetmiştir. Bu açıdan Obama daha resmi bir konuşma yaparken; Trump konuşmasını gösteriye çevirmiş ve başarısının 
DÖNMEZ, Enes (2020). Başkanlık Konuşması Öldüren Eğlence: Bir Örnek Olay İncelemesi, Gümüşhane Üniversitesi İletişim Fakültesi Elektronik Dergisi (e-gifder), 8 (2), 1081-1110

zevkini çıkarmaya çalışmıştır. Trump, Obama'dan farklı olarak arkasına aldığ bayraklar ve flamalar ile Başkomutanlık rütbesini öne çıkarmaktadır.

İki liderin jest ve mimikleri incelendiğinde ise; Obama'nın duygularını oldukça sabitleyerek ve gizleyerek konuştuğu, kararlı bir ifade çizdiği; buna karşın Trump'ın tüm konuşması boyunca abartılı jest ve mimikler sergilediği görülmüştür. Obama'nın tonlamasında kararlılık görülmektedir. Trump ise daha komik ve sıra dışı bir tonlamada konuşmuştur.

İki liderin konuşmasına sentaktik açıdan bakıldığında; Obama lafı dolandırmadan direk olarak durumu açıklayıp nedenler ve sonuçlarını da özet şekilde anlatmıştır. Obama'nın konuşmasında bağlantılar dikkatlice kurulmuş ve konudan konuya profesyonelce geçiş yapılarak akıcı bir sıralama oluşturulmuştur. Trump'ın konuşması sentaktik açıdan Obama'nınki ile büyük benzerlik göstermektedir. Bu açıdan bir öykünme olduğu da görülebilir. Ancak belirgin farklılıklar da mevcuttur.

Obama ve Trump konuşmalarında benzer sözcükler kullanmışlardır. İkisi de teröristlerin ölümünün neyin göstergesi olduğunu açıklarken "ölüm” yerine "demise" yani "vefat etmek" şeklindeki fiili kullanmışlardır. Başkomutanlık yetkilerine ikisi de yer vermiştir ve "masum çocuk”, "mağdurlar” benzerlik gösteren kısımlardır. Obama 9/11 olayları ile ilgili olarak duygusal bir yapı oluşturmak için mecazi sözcükler kullanırken; Trump, Bağdadi’nin nasıl kanlı bir katil ve sapık olduğunu göstermek için işlediği vahşetleri -üstelik jestleri ile destekleyerek- detaylı bir şekilde ve korkutucu sözcükler ile anlatmıştır. Trump, Obama'dan farklı olarak Bağdadi’nin ölüm şeklini "sızlanarak", "ç̧ı̆glık atarak", "ağlayarak", "korkarak” şseklindeki ifadeler ile anlatmıştır. Obama daha yumuşak bir tablo çizmeye çalışırken; Trump dehşet verici bir ölümden bahsetmektedir.

Her iki başkanda konuşmalarında görsel göstergelerden faydalanmışlardır. $\mathrm{Bu}$ sayede haklılıklarının insanların beyinlerine daha iyi kazınması amaçlanmıştır. Her ikisi de kendisinden önceki yönetimlerin sorunlarını çözdükleri için övünmüş ve kendilerini olumlamıştır. Ancak ek olarak Trump, başkan olmadan önce de etkisi olabileceğini, uyarılarda bulunduğunu ama onu dinlemedikleri için dünyanın bu halde olduğunu söylemiştir. Yazdığı kitaplar, yaptığı uyarılar konuşmasında şov 
DÖNMEZ, Enes (2020). Başkanlık Konuşması Öldüren Eğlence: Bir Örnek Olay İncelemesi, Gümüşhane Üniversitesi İletişim Fakültesi Elektronik Dergisi (e-gifder), 8 (2), 1081-1110

malzemesi olarak kullandığı örneklerdir. Obama Müslümanlar ile savaşmadıklarını dile getirirken; Trump konuşmasında böyle bir konuya değinmez.

Metinlerarasılık analizleri incelendiğinde ise; Obama ve Trump, ikisi de terör örgütlerinin katliamlarını görsel metinlerarasılıktan faydalanarak dile getirmişlerdir. Obama kendinden önceki Başkan Bush'un konuşmalarından faydalanmış ve konuşmasını güçlendirmiştir. Bu yaklaşımlar aynı fikirlerde olduklarını gösteren yaklaşımlardır. Clinton, Papa 2. John Paul vb. Hristiyan veya ABD’li önemli kişilerin konuşmalarından metinlerarası ilişkiler göze çarparken; CIA'in terörle mücadelede söz ettiği ve aynı zamanda ABD ulusal savunmasında kullanılan söylemlere yer vermiştir. ABD bağlılık sözleşmesi ile direk bir metinlerarasılık ilişkisi kurmuştur ve konuşmasının resmi bir temele oturtulduğu görülmektedir.

Trump konuşmasında ise; genel çerçevede Obama'nın konuşması ile metinlerarası bir ilişki göze çarpmaktadır. Trump bunun dışında taklitler ve pastişler ile metinlerarası ilişki kurmuştur. Genelde kurduğu bu ilişkiler geçmişteki kendi metinlerini direk alıntılama, çevresindeki diyalogları alıntılama ya da kim olduğu belli olmayan kişilerden yaptığı alıntılardır. Bunlar aslında kendisini haklı çıkarmak için dile getirilmiş, birçoğu pek de güvenilir olmayan alıntılardır. Hem konuşmayı kendi istediği çerçevede tutmak hem de kendisini kendi ile haklı çıkarma çabasıdır. Aynı zamanda bütün krediyi kendisinin toplaması da göze çarpmaktadır. Taklitleri yaparken gösterdiği jest ve mimikler; konuşmasını nasıl bir gösteriye çevirdiğini göstermektedir. Yukarıda ele alınan Obama ve Trump'ın konuşmalarının karşılaştırılması Tablo 1'de de sunulmaktadır.

Tablo 1: Obama ve Trump'ın Konuşmasının Karşılaştırılması

\begin{tabular}{|l|l|}
\hline Obama'nın Konuşması & Trump'ın konuşması \\
\hline 9 dakika 18 saniye & 48 dakika 5 saniye \\
\hline Operasyonun özetlenmesi & Operasyonun detaylı anlatımı \\
\hline Soru cevap yok & Soru ve cevap var \\
\hline Askeri göstergeler yok & Askeri göstergeler var \\
\hline Az jest ve mimik & Fazla jest ve mimik \\
\hline Resmi & Gayri resmi \\
\hline Özgün & Fazla alıntı (Obama'nın konuşmasına benzerlik) \\
\hline Şiddet yumuşatılmıştır & Şiddet net bir biçimde ifade edilmiştir \\
\hline Görsel göstergelerden faydalanmıştır & Görsel göstergelerden faydalanmışır \\
\hline İslamiyet'e sıcak bir bakış & İslamiyet'e karşı sert bir tutum \\
\hline Ekonomik nedenler yok & Ekonomik nedenler var \\
\hline
\end{tabular}


DÖNMEZ, Enes (2020). Başkanlık Konuşması Öldüren Eğlence: Bir Örnek Olay İncelemesi, Gümüşhane Üniversitesi İletişim Fakültesi Elektronik Dergisi (e-gifder), 8 (2), 1081-1110

\begin{tabular}{|l|l|}
\hline Metinlerarasılık var & Metinlerarasııı var \\
\hline Siyasi ve milli alıntılar & Belirsiz ve kendinden alıntılar \\
\hline Dayanaklı alıntılar & Dayanaksı alıntılar \\
\hline
\end{tabular}

Trump'ın kendine has tavrı ve görünüşü birçok komedyen tarafindan taklit edilerek mizah malzemesi olarak kullanılmıştır. Trump bu taklitlere hiç eleştiri getirmediği gibi, kendisi de alet olmuştur. Yıllarca birçok Hollywood filminde küçük roller almak için çabalamış, bir reality show programı sunmuş ve ilginç televizyon programlarına konuk olmuştur. Binalara kendi adını vermiş ve hepsi Trump'ın gösterisine hizmet etmiştir.

Campbell ve Jamieson'ın (2008) başkanlık konuşması ve türlerini hakkındaki çalışması ve Coe'nin (2017), külliyat odaklı çalışması bu çalışmaya ön ayak olmuştur. Bunun yanı sıra Trump ve diğer ABD başkanlarının konuşmalarını farklı analiz biçimleri ile inceleyen çalışmalar ise şunlardır; Suhadi ve Baluqiah (2017), stilistik analizin yöntemi ile Obama ve Trump'ın konuşmalarını incelemiş ve Trump'ın seçilmiş bir başkan olarak yaptığ 1 açılış konuşmasında, bir Hollywood filmi olan "Batman: Kara Şovelye Yükseliyor" filmindeki Bane karakteri ile kurduğu metinlerarası ilişki gibi örnekleri ortaya koymuştur. Ayrıca medyada "Legally Blonde" filminde Elle Woods karakteri ile kurduğu metinlerarası ilişkiye sarkastik bir şekilde yer verilmiştir. Gösteriden faydalanan Trump; konuşmalarını ve iletişimini bu format ile etkileyici bir hale getirmeye çalışmıştır. Belisle vd. (2018), Clinton'dan bu yana, ABD başkanlarının, açılış konuşmalarını davranışsal analiz çerçevesinde incelemişlerdir. Belisle vd., dört ABD Başkanı'nın sergilediği dokuz farklı bağlantısal davranış türü ile ele almışlardır. Liu ve Lei'nin (2018)'de Hillary Clinton ve Donald Trump'ın 2016 seçim konuşmaları nicel bir yaklaşım ile duygu analizi ile incelemiştir. Böylelikle Trump ve Clinton'ın kampanya boyunca sürdürdükleri konuşma stratejilerindeki farklılıkları ortaya koymuştur. $\mathrm{Bu}$ araştırmada yer verilen Obama ile Trump'ın terörist liderlerin ölümünü açıkladığ konuşmaların göstergebilimsel analizi ve metinlerarası analizi ise başkanların konuşmalarındaki gösteri olgusunu ortaya koymaktadır. Böylelikle televizyonun başkanlık konuşmasını dahi bir gösteriye çevirdiği yanıtı bulunmaktadır. Araştırma sorularında ortaya konulan sorunsallar göz önünde bulundurulduğunda, Trump'in 
DÖNMEZ, Enes (2020). Başkanlık Konuşması Öldüren Eğlence: Bir Örnek Olay İncelemesi, Gümüşhane Üniversitesi İletişim Fakültesi Elektronik Dergisi (e-gifder), 8 (2), 1081-1110

televizyondan 48 dakika boyunca aşırı jest ve mimikler, taklitler, komik alıntılar, sürekli kendine kredi sağlamaya çalışması izleyiciye sunulan gösteri olgusunu ortaya koymaktadır. Sayısız terör mağdurunun ve bir terör liderinin öldürülmesinin detaylı bir şekilde anlatımı bir gösteriye dönüşmüş ve toplum bu konuda dahi bir eğlence formatına maruz kalmıştır. Peki, bunları yaparken içerik ne derece konuşulmuştur?

Gösteri ile üstü örtülmeye çalışan gerçeklik nedir? Son araştırma sorunun cevabı ise Trump'ın konuşmasından örnekler ile incelemek fayda sağlayacaktır. ABD'nin petrol için Orta Doğu'da olduğu söylemi birçok kişi tarafindan dile getirilse de bugüne kadar yetkililerin ağzından direk olarak duyulmamıştır. İlk defa bu kadar önemli bir resmi duyuruda Trump bunu direkt olarak açıklamıştır. Bu bir ironiye sebep olmaktadır. Öncelikle bugüne kadar yapılan eleştirileri haksız çıkarmış gibi görünmektedir. Çünkü Trump'ın göre; önceki yönetimler petrolden faydalanamamışlardır. Aksine yüz milyarlarca dolar kaybetmişlerdir. Ancak şimdide Trump siyasi bir doğruculuk yaparak petrolü korumak için orada olacağını söylemektedir. Ancak bu da başka bir ironiyi doğurmaktadır; petrol savunmasız kalırsa terör örgütlerinin eline geçip, onları besleyecektir. Tek savunucusu ise ABD ve onun uygun gördüğü "Exxon Mobile” gibi bir şirket olduğu dile getirilmiştir. İç politikada Trump'ın ekonomiyi güçlendirme ile ilgili saplantısı ve ABD ekonomisinin güçlenmesini isteyen halk nazarında bu söylem kabul görürken; dışarıda Trump'ın tavırları ve şovmenliği alay konusu olmuştur. Bu konu, televizyon ve köşe yazılarında komik bir üslup ile alaycı bir tavırla yaklaşılarak sulandırılmıştır. Trump'ın ve ABD siyasetinin bir şova dönüşmesi, yaptığı her hamlenin artık “medyatik" bir değer taşımasına sebep olmuş ve bunun içeriğinden çok medyatikliği ve şovu üzerine konuşulur hale gelmiştir.

Trump'ın gösterisi insanları eğlendirmekte veya ciddiye alınmamasını sağlamaktadır. Ancak elindeki yetkiler, söylediklerini gerçekleştirebilecek güçte olduğunu göstermektedir. Geldiği günden bugüne belki de komedi programlarına ve talk showlara en çok malzeme olmuş ABD başkanı olabilir. Ancak azil sürecindeki konulara, bugüne kadar adının karıştığı skandal ve suçlamalara, konuşmasındaki Orta Doğu hakkındaki planlarına bakılacak olursa; Trump nasıl oluyor da doğru kişi olarak görülüyor sorusunun cevabı; "eğlenceli biri” olabilir. 
DÖNMEZ, Enes (2020). Başkanlık Konuşması Öldüren Eğlence: Bir Örnek Olay İncelemesi, Gümüşhane Üniversitesi İletişim Fakültesi Elektronik Dergisi (e-gifder), 8 (2), 1081-1110

\section{KAYNAKÇA}

AKTULUM, Kubilay (2011). Metinlerarasılık/Göstergelerarasılık, Ankara: Kanguru Yayınları.

AÜSTERMÜHL, Frank (2014). The Great American Scaffold "İntertextuality and Identity in American Presidential Discourse" Amsterdam, Philadelphia: John Benjamins Publishing Company.

BELISLE, Jordan; PALILIUNAS, Dana; DIXON, R. Mark ve TARBOX, Jonathan (2018). "Feasibility of Contextual Behavioral Speech Analyses of US Presidents: Inagural Adresses of Bill Clinton, George W. Bush, Barack Obama, and Donald Trump, 1993-2017”, Journal of Contextual Behavioral Science, Say1:10, s. 14-18.

BEYAZ SARAY; (1997). One America in the 21 st Century Forging a New Future, https://clintonwhitehouse2.archives.gov/Initiatives/OneAmerica/PIR.pdf, Erişim Tarihi: 08.12.2019.

BEYAZ SARAY; (2001). Presidential Address to the Nation, https://georgewbushwhitehouse.archives.gov/news/releases/2001/10/20011007-8.html, Erişim Tarihi: 07.12.2019.

CAMPBELL, Karlyn Kohrs ve JAMIESON, Kathleen Hall (2008). Presidents Creating the Presidency: Deeds Done in Words, Chicago: University of Chicago Press.

CENTRAL INTELLIGENCE AGENCY; (2003). "National Strategy For Combating Terroris", https://www.cia.gov/news-information/cia-the-war-onterrorism/Counter_Terrorism_Strategy.pdf, Erişim Tarihi: 07.12.2019

CNN (1995). Transcript of President Clinton's Speech on Race Relations, http://edition.cnn.com/US/9510/megamarch/1016/clinton/update/transcript.ht ml, Erişim Tarihi: 08.12.2019.

COE, Kevin (2017). Presidential Address, (Editörler), Kate Kenski ve Kathleen Hall Jamieson. The Oxford Handbook of Political Communication, New York: Oxford University Press. 
DÖNMEZ, Enes (2020). Başkanlık Konuşması Öldüren Eğlence: Bir Örnek Olay İncelemesi, Gümüşhane Üniversitesi İletişim Fakültesi Elektronik Dergisi (e-gifder), 8 (2), 1081-1110

DEBORD, Guy (2019). Gösteri Toplumu, (Çev: Ayşen Ekmekçi ve Okşan Taşkent),

9. Basım, İstanbul: Ayrint1.

DECOSTER, Jamie ve LINCHTENSTEIN, Bronwen (2012). İletişim Araştırmalarında Nicel ve Nitel Yöntemleri Bütünleştirme (Çev: Şevki Kılıç), (Editör), Özlem Güllüoğlu. İletişim Bilimlerinde Araştırma Yöntemleri; Görsel Metin Çözümlemesi, 1.Baskı, Ankara: Ütopya.

DEVRAN, Yusuf (2017). Haber, Söylem, İdeoloji, 1. Baskı, İstanbul: Başlık.

KAMISAR, Ben (2016). Trump bashes Rubio: He's a 'little frightened puppy', https://thehill.com/blogs/ballot-box/presidential-races/270946-trump-bashesrubio-hes-a-little-frightened-puppy, Erişim Tarihi: 25.12.2019

KELLNER, Dougles (2010). Medya Gösterisi, (Çev: Zeynep S. Doğruer), İstanbul: Açılım Kitap.

KLEIN, Ezra (2018). Amusing ourselves to Trump, https://www.vox.com/policyand-politics/2018/8/6/17599010/neil-postman-trump-amusing-ourselves, Erişim Tarihi: 07.09.2020.

KÖKER, Eser; (2007). Politikanın İletişimi, İletişimin Politikası, Ankara: İmge Kitabevi.

LIMA, Cristiano (2017). Trump: North Korea's Kim a 'sick puppy', https://www.politico.eu/article/donald-trump-north-koreas-kim-a-sickpuppy/, Erişim Tarihi: 25.12.2019.

LIU, Dilin ve LEI, Lei (2018). "The Appeal to Political sentiment: An Analysis of Donald Trump's and Hillary Clinton's Speech Themes and Discourse Strategeis in The 2016 US Presidential Election", Discourse, Context \& Media, Say1:25, s. 143-152.

MORRIS, David (2004). American Voice 2004: What is the background of the Pledge of Allegiance?, Institute For Local Self-Reliance, https://ilsr.org/whatis-the-background-of-the-pledge-of-allegiance/, Erişim Tarihi: 05.12.2019

PAPA 2. John Paul (1995). “Adress of His Holiness John Paul II”, The Fifth General Assembly of The United Nations Organization, 
http://www.vatican.va/content/john-paulii/en/speeches/1995/october/ documents/hf_jp-ii_spe_05101995_address-to-uno.html, Erişim Tarihi: 08.12.2019.

PERLOFF, Richard, M. (2010). The Digital Dynamics of Political Communication: Media and Politics in a Digital Age, New York: Routledge.

POSTMAN, Neil (2016). Televizyon Öldüren Eğlence: Gösteri Çağında Kamusal Söylem, (Çev: Osman Akınhay), 6. Basım, İstanbul: Ayrıntı.

SUHADİ, Agung; BALUQİAH, Kiagus (2017). "Donald Trump and Barrack Obama's Inaugural Address: Stylistic Analysis”, ISELT-5, Sayı:5, s. 169177.

THE DENVER POST (2008). Remembering Sept. 11, 2001, https://www.denverpost.com/2008/09/10/remembering-sept-11-2001/, Erişim Tarihi: 05.12.2019

THE GUARDIAN; (2002). George Bush's Speech in Berlin, https://www.theguardian.com/world/2002/may/23/usa.georgebush, Erişim Tarihi: 07.12.2019.

THE NEW YORK TIMES; (2008). Obama's National Security Team Announcement, https://www.nytimes.com/2008/12/01/us/politics/01textobama.html, Erişim Tarihi: 07.12.2019

THE WASHINGTON POST; (2001). President Bush Addresses the Nation, https://www.washingtonpost.com/wpsrv/nation/specials/attacked/transcripts/b ushaddress_092001.html, Erişim Tarihi: 25.12.2019.

WINT, Theodore Otto Jr. (1986). "Presidential Rhetoric: Definition of a Field of Study." Central States Speech Journal, Say1:16, No:1, s.102-116, https://debate.uvm.edu/asnider/campreadings/03February\%205/Windt,\%20Pr esidential\%20Rhetoric\%20-\%20definition.pdf, Erişim Tarihi: 01.01.2020. 